\title{
Population changes of Tuta absoluta (Gelechiidae) and fruit loss estimates on three tomato cultivars in greenhouses in Biskra, Algeria
}

\author{
Farid Allache ${ }^{1 *}$, Fatma Demnati ${ }^{1,2}$, Mohamed Amine Houhou ${ }^{3}$ \\ ${ }^{1}$ Department of Agricultural Sciences, University of Biskra, BP 145 RP, 07000 Biskra, Algeria \\ ${ }^{2}$ Laboratory of Ecosystem Diversity and Agricultural Production System Dynamics in the Arid Areas (DEDSPAZA), University of \\ Biskra, BP 145 RP, 07000 Biskra, Algeria \\ ${ }^{3}$ Direction of Agricultural Statistics (DSA), 07000, Biskra, Algeria
}

*Corresponding author, E-mail: f.allache@univ-biskra.dz, allachefarid@yahoo.fr

\begin{abstract}
The aim of this study was to monitor Tuta absoluta population development in greenhouse conditions on different tomato cultivars. All pest stages were present on all the cultivars. The development of T. absoluta was variable and depended both on temperature and tomato cultivar. Losses due to development of T. absoluta larvae on the fruit were estimated at $43.3 \%$ on cv. 'Sahara', $3 \%$ on cv. 'Dawson', and $17 \%$ on cv. 'Toufan'. Percentage of fruit losses was positively correlated with increase in number of larvae. The attacks were more severe during the spring period with rising temperatures. Strong applications of pesticides used to control various tomato pests resulted in absence of antagonists in the greenhouse. Cultivars 'Toufan' and 'Dawson' were less suitable for cultivation in conditions of heavy leaf miner infestation; this characteristic may be associated with other control methods to reduce plant damage.
\end{abstract}

Key words: fruit losses, population changes, tomato, Tuta absoluta.

\section{Introduction}

Tomato (Lycopersicon esculentum L.) is cultivated around the world both in greenhouses and open fields (Lange, Bronson 1981). It is an annual solanaceous plant native to the Andes and America; it is cultivated for its fruit, which can be consumed fresh and in processed forms (Chaux, Foury 1994; Gebremariam 2015).

Vegetable cultivation holds an important position in the economy and for human consumption in Algeria. According to 2014 statistics, 5285 ha were dedicated to greenhouse vegetable production in Biskra. The main crops include tomatoes with 2190 ha (41\%), followed by chilies (1220 ha), peppers (830 ha), eggplants (420 ha), zucchini (254 ha) and cucumbers (240 ha). In term of production, tomato cultivation ranks first with over $293070 \mathrm{t} \mathrm{year}^{-1}$; representing an average yield of $135 \mathrm{t} \mathrm{ha}^{-1}$. Amongst Biskra municipalities, Ain Naga was classified as the largest producer of early tomato fruits nationally, with over 23750 greenhouses, made up of 13750 tunnel greenhouses and 41 ha multichapel greenhouses (DSA Biskra 2014).

Currently, one third of the world's agricultural production is destroyed due to different pests such as insects and diseases, which cause considerable damage throughout all stages of production (Guenaoui 2008). One of the most common pests in recent years in Europe and North Africa is the tomato leaf miner Tuta absoluta Meyrick (Desneux et al. 2010; Caparros-Megido et al.2012; Caparros-Megido et al. 2013), with numerous infestation outbreaks along the Mediterranean coast (Urbaneja et al. 2007). It has caused considerable loss both in greenhouses and open fields. Damage caused to the fruit can serve as an entry point for pathogens (Kaoud 2014). Managing this pest remains very difficult due to its hidden behavior during the immature stages (Ghoneim 2014; Terzidis et al. 2014). Harvest losses have reached 80 to $100 \%$ (Gebremariam 2015) and increased production costs have resulted mainly from increased protection costs (Retta, Berhe 2015).

Lacordaire, Feuvrier (2010) highlight the seriousness of the T. absoluta to many solanaceous plants. Reported in 1935 for the first time in South America, its invasion has increased worldwide. T. absoluta is highly resistant to insecticides (Siqueira et al. 2000).

In Algeria, the first appearance of this pest was in coastal zones of Mostaganem (North-West of Algeria) in March 2008 , and then it rapidly spread to other regions (Guenaoui 2008). It was first reported in 2009 in Biskra (Allache, Demnati 2012; Allache et al. 2012). Due to damage caused by this pest throughout the world, several studies have been conducted on its bio-ecology and population dynamics to better manage and preserve tomato crop production. Tomato cultivation has an important economic value for 
the population at both the local and national levels. At the time of this research, only tomato plants were attacked by the South American leaf miner in Biskra (Allache, Demnati 2012; Allache et al. 2012).

The aim of this study was to monitor T. absoluta population development in greenhouse conditions on different tomato cultivars. Three objectives were put forward: (1) to monitor population changes of T. absoluta on tomato cultivars 'Sahara,' 'Dawson' and 'Toufan', (2) to detect the first flight of adults and (3) to determine the percentage of affected fruit in Ain Naga (south-east of Biskra).

\section{Materials and methods}

\section{Study area}

Ain Naga $\left(34^{\circ} 42^{\prime} 10.13^{\prime \prime} \mathrm{N}, 5^{\circ} 59^{\prime} 56.74^{\prime \prime} \mathrm{E}\right)$ is located in the south-east part of Biskra in an arid bioclimatic zone. The study was performed on one farm using three greenhouses, each containing a different tomato hybrid cultivar ('Sahara', "Dawson" and "Toufan"). These cultivars were chosen because of their agro-technical characteristics including fungal disease resistance, good fruit size, plant vigour etc. The greenhouses had a surface area of $400 \mathrm{~m}^{2}$, i.e. $50 \mathrm{~m}$ long and $8 \mathrm{~m}$ wide. Cultivation techniques used in greenhouses were plowing, hoeing, weeding, mulching, trellising and fertilisation; the greenhouses also had drip irrigation systems. For disease and pest management, chemicals were used during the tomato cultivation cycle. Table 1 summarises the chemicals used to control the tomato pests and diseases. The greenhouses used in this study were kept free of weeds. Seedlings were transplanted into greenhouses in September 2014.

\section{Adult capture and immature sampling method}

Two methods were used to monitor tomato leaf miner population changes, as described by Allache, Demnati (2012) and Allache et al. (2012). Pheromone traps were used to catch T. absoluta adult males. For this, three pheromone traps were placed, two at each greenhouse entrance and one in the centre. They were set from the seeding until the end of cultivation. Pheromone capsules were renewed every

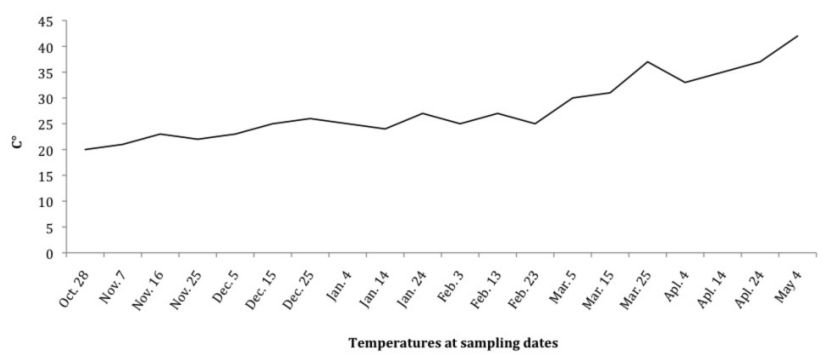

Fig. 1. Recorded temperatures in greenhouse at sampling dates.

4 to 6 weeks. The purpose of pheromone trap use was to detect the start of adult flights and study the population fluctuations. The number of adults caught and temperature records were made every ten days. Temperature was recorded between 09:00 and 11:00 in situ at the time of leaf sampling with an instant read thermometer. Fig. 1 shows temperature changes during sampling period.

A sampling of leaves for counting immature stages was performed periodically. Fifty leaves were randomly taken from 50 plants of each tomato cultivar; they were brought to laboratory and observed under a dissecting microscope. Eggs and larvae were counted on each leaf.

\section{Evaluation of infested fruits}

For estimating infested fruits caused by larvae, a sample of 30 plants was taken randomly at the beginning of fruit appearance (green fruit). Then, approaching the harvest date, a new sampling of tomato fruits was carried out. Thirty individual fruits were taken randomly per cultivar every week. Holes caused by larvae infestations were counted. Infestation was calculated as follows:

Infested fruit $(\%)=$ (Number of tomatoes with holes / Total number of tomatoes) $\times 100$.

\section{Statistical analysis}

Data obtained were transformed using a square root transformation to obtain normal distribution and subjected to Anova analysis and Newman-Keuls test to compare and detect significant differences between means at $p<0.05$. Correlation between numbers of forth larvae of tomato leaf miners and damage observed was calculated.

Table 1. Pesticides used for different pest control on all tomato cultivars. A knapsack sprayer of $16 \mathrm{~L}$ capacity was used. Used pesticide frequencies; employed doses and pests targeted by farmer were reported. WP, wettable powder; EC, emulsifiable concentrate

\begin{tabular}{|c|c|c|c|c|}
\hline Active ingredient & Type & Dose used & Timing of application & Managed pests \\
\hline Mancozeb (80 \% WP) & Fungicide & 50 g per $16 \mathrm{~L}$ & Each 15 days & \multirow[t]{2}{*}{ Botrytis, Alternaria } \\
\hline Iprodione (500 $\left.\mathrm{g} \mathrm{kg}^{-1}\right)$ & Fungicide & $24 \mathrm{~g}$ per $16 \mathrm{~L}$ & Six times & \\
\hline Abamectin $\left(18 \mathrm{~g} \mathrm{~L}^{-1}\right)$ & Insecticide/Acaricide & $10 \mathrm{~mL}$ per $16 \mathrm{~L}$ & Each 15 days & \multirow[t]{2}{*}{ Mites, Agromyzides } \\
\hline Dicofol (18.5 EC) & Acaricide & $16 \mathrm{~mL}$ per $16 \mathrm{~L}$ & Once & \\
\hline Oxamyl (10\%) & Insecticide & & Four times & \multirow{3}{*}{$\begin{array}{l}\text { Whiteflies, aphids, moths, thrips, } \\
\text { Tuta absoluta }\end{array}$} \\
\hline Methomyl (200 $\left.\mathrm{g} \mathrm{L}^{-1}\right)$ & Insecticide & $24 \mathrm{~mL}$ per $16 \mathrm{~L}$ & Each 7 days & \\
\hline Acetamiprid (20\%) & Insecticide & 10 g per $16 \mathrm{~L}$ & Each 15 days & \\
\hline
\end{tabular}




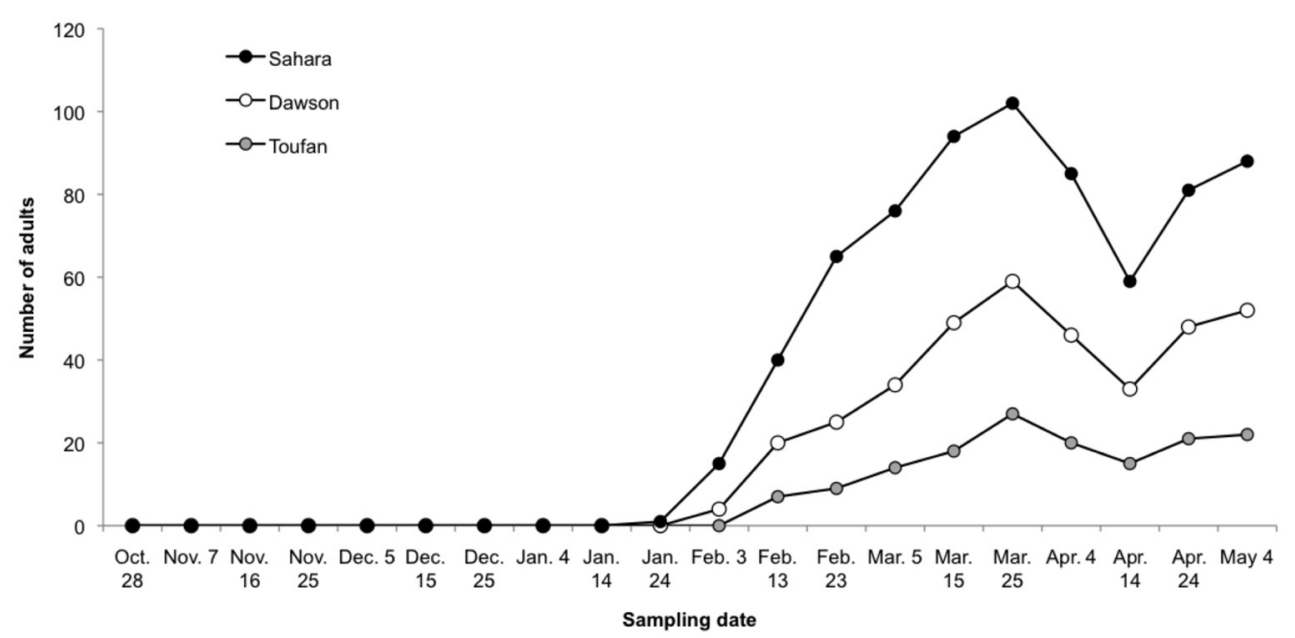

Fig. 2. Adult population changes in greenhouse on three cultivars of tomato crop at Biskra (October 2014 to May 2015). Data of adult counts were obtained from pheromone traps. They were registered each ten days.

\section{Results}

\section{Adult flight and population changes of adults}

The onset of the first adults' flight was noted on the 'Sahara' cultivar on January $24^{\text {th }}, 2015$; February $3^{\text {rd }}, 2015$ on 'Dawson' and February 13 ${ }^{\text {th }}, 2015$ on 'Toufan' (Fig. 2 ). Following the first adult catch, a variable increase in population size depending on cultivar was recorded. There were 27 individuals captured on the 'Toufan' cultivar, while 32 individuals on 'Dawson'. A high number was observed on the 'Sahara' cultivar with 45 individuals. This increase in adult population was seen at the end of February and during March. This was followed by decreasing numbers between March $25^{\text {th }}$ and April 14 $4^{\text {th }}, 2015$. The number of individuals decreased on the 'Sahara' cultivar from 45 to 26 and from 32 to 18 on the 'Dawson'; and on 'Toufan', the numbers dropped from 27 to 15 . After this point, we observed an increase in size until the end of the tomato cycle. The numbers of individuals captured on the different cultivars were 22 adults on 'Toufan', 30 on 'Dawson' and and 36 on 'Sahara'. The total number of adults caught by pheromone traps throughout the study period on all cultivars amounted to 336 adults on 'Sahara', 217 adults on 'Dawson' and 153 adults on 'Toufan' (Fig. 2). Statistical analysis showed significant difference between individual numbers captured on the three tomato cultivars ( $F=$ 5.80; $p=0.007)$. The Newman-Keuls test revealed that adult numbers caught in the 'Sahara' cultivar greenhouse significantly differed from that on 'Dawson' and 'Toufan' cultivars. Numbers of adults between the last two cultivars was not significantly different.

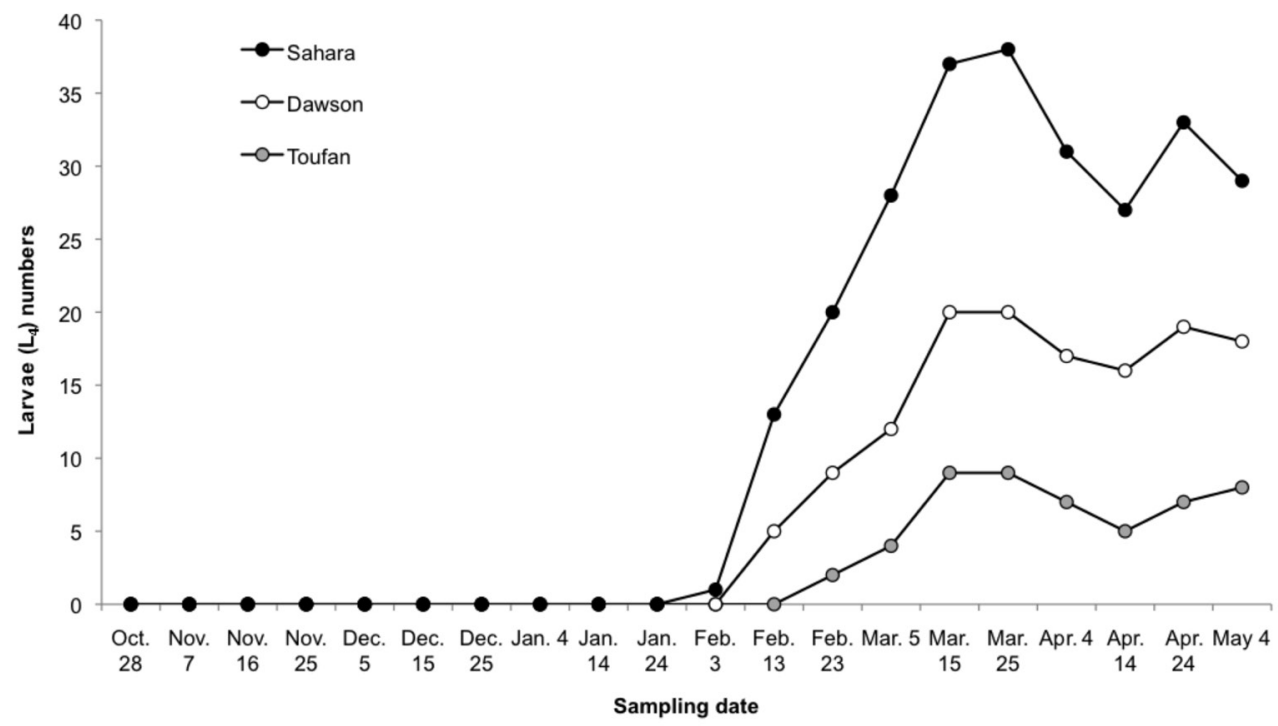

Fig. 3. Fluctuation of population numbers of Tuta absoluta fourth instar larvae on three tomato cultivars (October 2014 to May 2015). The numbers of fourth stage larvae were counted on 30 tomato leaves sampled at random. 
Table 2. Mean and total numbers of eggs and larval stage of Tuta absoluta on three tomato cultivars. Eggs and larvae were counted on leaflets by sampling 30 tomato leaves periodically, each ten days. The same letter in lowercase in the same column means that difference is not significant

\begin{tabular}{lcccc} 
Tomato cultivar & Total of eggs & Mean of eggs & Total of larvae & Mean of larvae \\
'Toufan' & 47 & $2.35 \pm 3.63 \mathrm{a}$ & 133 & $6.65 \pm 9.46 \mathrm{a}$ \\
\hline 'Dawson' & 84 & $4.20 \pm 4.74 \mathrm{~b}$ & 242 & $12.10 \pm 14.31 \mathrm{ab}$ \\
\hline 'Sahara' & 102 & $5.10 \pm 5.34 \mathrm{~b}$ & 354 & $17.70 \pm 20.58 \mathrm{~b}$
\end{tabular}

\section{Fourth larvae population changes}

Larvae were lacking at the start of leaves sampling (Fig. 3). The occurrence of this stage started on February $23^{\text {th }}$, 2015 on the 'Toufan' cultivar, on February $13^{\text {th }}$, 2015 on the 'Dawson' and ten days before on the 'Sahara' cultivar (February $3^{\text {rd }}$, 2015). Temperature at this period was between 25 and 27 ${ }^{\circ} \mathrm{C}$. The number of larvae was variable according to tomato cultivar. The largest numbers of larvae were recorded on the 'Sahara' cultivar (121 fourth instar larvae), then 'Dawson' (85 L4) and finally 'Toufan' (51 L4). Maximum number of fourth instar larvae (18 individuals) was registered on Marsh 25th, 2015 for the 'Sahara' cultivar, 12 individuals on 'Dawson' on April $24^{\text {th }}$ and finally nine individuals on the 'Toufan' cultivar on March $15^{\text {th }}$ and $25^{\text {th }}, 2015$. There was an overall decrease in larvae number after this period until the end of the plant's cycle. Statistical analysis showed that there was a significant difference between the number of fourth instar larvae developing on the different cultivars $(F=4.92$; $p=0.014)$. The Newman-Keuls test showed that number of fourth instar larvae individuals on the 'Sahara' cultivar was significantly different from those on 'Toufan', however, number on the 'Dawson' cultivar was not significantly different from that on 'Sahara' and 'Toufan' cultivars.

\section{Suitability of tomato cultivars to egg-laying and larvae development}

The average numbers of eggs laid and larvae counted of $T$. absoluta in the three greenhouse cultivars are presented in Table 2. It was noticed that the average number of deposited eggs and sampled larvae were low on 'Toufan' cultivar. However these numbers were greater on 'Dawson' and 'Sahara' cultivars. Statistical analysis showed that the difference between eggs laid on all cultivars was significant $(F=5.17 ; p=0.012)$. The Newman Keuls test showed that this number was different between 'Toufan' and 'Sahara'। 'Dawson' cultivars. There was no significant difference between the 'Sahara' and 'Dawson' cultivars. Regarding larvae, it appeared that the difference between the number of sampled larvae on leaves between the three cultivars was significant $(F=6.18, p=0.006)$. However, the number of larvae on 'Sahara' cultivar was significantly different from that on 'Toufan'.

\section{Tomato fruits losses}

Damage on tomato fruit was monitored regularly. At the beginning of the observation period, all of the sampled fruits were healthy (Fig. 4). The first appearance of damage

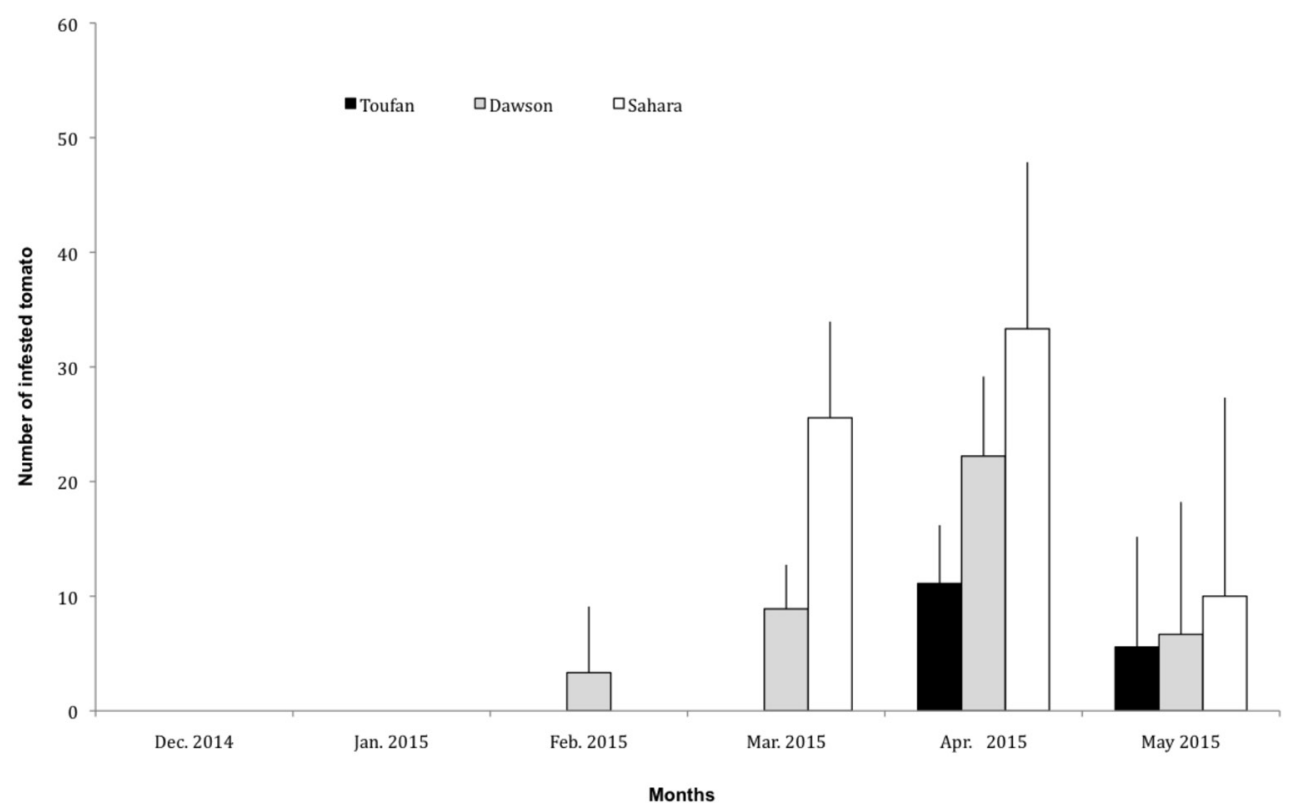

Fig. 4. Number of infested fruits (\%) due to Tuta absoluta on three tomato cultivars under greenhouse condition. Tomato fruits of the three cultivars were observed from December. Prior to harvest, the fruits were observed on the plant. At harvest, a fruits sampling was carried out periodically each ten days, randomly. They were expressed per month. 
Table 3. Mean percentage of infested tomato fruits and correlation between numbers of fourth instar larvae and infestation on all cultivars. At the beginning of fruit appearance, damage due to tomato borer were screened at random in situ, then tomato samples were took out towards harvest every ten days. Lowercase letter in column indicated that there was no difference between percentages of tomato fruits losses. Correlation between larvae numbers and fruits loss was positive

\begin{tabular}{lcc} 
Tomato cultivar & Infested fruit (\%) & Correlation $\mathbf{r}$ \\
'Toufan' & $2.50 \pm 5.50 \mathrm{a}$ & 0.58 \\
\hline 'Dawson' & $6.17 \pm 9.13 \mathrm{ab}$ & 0.83 \\
\hline 'Sahara' & $10.33 \pm 15.59 \mathrm{~b}$ & 0.80
\end{tabular}

was variable depending on the cultivar. The first damage appeared first on the 'Dawson' cultivar on February $23^{\text {th }}$, 2015 with $10 \%$ of the fruit being infested and $17 \%$ for the other two cultivars ('Sahara' and 'Toufan'). For 'Sahara', damage began on March $5^{\text {th }}$ and on 'Toufan' it appeared on April $4^{\text {th }}, 2015$. Damage differed between samples for all tomato cultivars. All tomato cultivars had fruit damage; however, the damage was more extensive on the 'Sahara' cultivar compared to the other two cultivars. The percentage of damage reached a maximum of $43.3 \%$ onthe 'Sahara' cultivar, $30 \%$ on 'Dawson' on April $24^{\text {th }}$, and $17 \%$ on 'Toufan' in April and May, 2015.

The average percentage of damage caused by larvae of $T$. absoluta on tomato fruit on all cultivars is recorded in Table 3. Statistical analysis showed that the difference between means was significant $(F=3.39 ; p=0.031)$. Tomato fruit damage due to leaf miners was significantly positively correlated with larvae population changes.

\section{Discussion}

Although Algerian farmers are familiar with this new pest, it remains a major threat for tomato production in the Biskra region. We have demonstrated that there is a need to combat it, however friendly control methods could be developed. The lack of natural antagonists indicates an overuse of pesticides by the farmer. The South American tomato borer can persist and develop in arid expanse where tomato cultivation is grown, such as in Biskra, and they are capable of causing total losses of production. The study pointed out that 'Toufan' and 'Dawson' varieties are most appropriate for cultivation in this region.

Currently, this pest is distributed around the world. It has an important potential for not only geographical expansion, but also of development on other plants (Desneux et al. 2010). T. absoluta preferred using tomatoes as host plant rather than potatoes or eggplants (Sridhar et al. 2015). In Biskra, Bouchagroune, Sidi Okba and Droh, the tomato leaf miner was recorded only in tomato cultivation; it is presently considered among the common pests in Algeria (Allache, Demnati 2012; Allache et al. 2012; Allache et al. 2015).
The first adult flight was spread out between January $24^{\text {th }}$ until February $13^{\text {th }}, 2015$, where temperatures recorded ranged between 25 and $27^{\circ} \mathrm{C}$ in Ain Naga. It seems that adult emergence was variable in the same region. Thus, in Biskra it was registered on December $15^{\text {th }}, 2010$ (Allache et al. 2012), and in November and December respectively in Bouchagroune and Sidi Okba (Allache, Demnati 2012). In Droh (East of Biskra) adults were detected in traps on October 27th 2011 (Allache et al. 2015). At Mascara (West of Algeria), Elouissi, Berkani (2015) registered the first adults in pheromone traps on December $15^{\text {th }}, 2013$.

Changes in the imaginal population on the three tomato cultivars ('Toufan', 'Dawson' and 'Sahara') indicated a weak presence of adults during the autumn-winter period, which extended from the start of study through March 15 $5^{\text {th }}, 2015$. The greatest number of adults captured during this period was 18 individuals on 'Toufan', 31 on 'Dawson' and 45 on 'Sahara'. Recorded temperatures ranged between 20 and 31 ${ }^{\circ} \mathrm{C}$. The largest number of adults was captured on March $25^{\text {th }}, 2015$ (27 in the 'Toufan' cultivar greenhouse, 32 and 43 respectively for 'Dawson' and 'Sahara' greenhouses). This was followed by a drop in number of captured adults; however, it remained low until the end of tomato cultivar cycle. The temperature recorded during this period was between 37 and $42{ }^{\circ} \mathrm{C}$. It appears that this decline in captured adults may be related to insecticide use (Abamectin and Oxamyl) against this pest by the farmer or to high temperature in the greenhouses; or both simultaneously. According to Lietti et al. (2005), Silvério et al. (2009) and Lebdi-Grissa et al. (2010) chemical control is considered as an effective management option for controlling T. absoluta population.

The present results were consistent with those of Allache, Demnati (2012), Allache et al. (2012) and Allache et al. (2015) in the same region. It seems that temperature influences development of the tomato leaf miner. However, Guenaoui (2008) showed that T. absoluta populations were regulated by abiotic factors, particularly temperature and humidity. An increasing number in adults caught at the end of the tomato cycle on all cultivars was observed. Lacordaire, Feuvrier (2010) and Allache et al. (2012) pointed out that number of adults caught increases during the growing season. The activity and intensity of adults trapped depends on temperature (Lacordaire, Feuvrier 2010). The damage was severe at the end of the tomato cycle (Leite et al. 2001). These authors always advised farmers to remove the previous crop debris in order to prevent re-infestation of the subsequent crops.

The study showed that all tomato cultivars hosted the different larval stages with variable numbers. Regarding population changes of larvae, an absence of larvae was observed in all cultivars early in the crop cycle, with gradual increases over time. Similar results were noted by Allache et al. (2012) in the same region and Chougar, MedjdoubBensaad (2014) in Tizi-Ouzou costal region on 'Dawson' cultivars. Miranda et al. (1998) linked the low presence of larvae to reduced numbers of hatched eggs and eggs 
infertility. However, larval mortality was estimated at 58.7\% by these authors. During the spring period, the larvae numbers increased on all cultivars, which was also noted by Allache et al. (2012) and Allache, Demnati (2012). This growth was due to high numbers of hatched eggs (Allache et al.2012) and temperature increases (Barrientos et al. 1998); however the number remained low. Martins et al. (2016) considered temperature as a key factor which affected the insect development. They registered low immature mortality between 28 and $30^{\circ} \mathrm{C}$ for T. absoluta. The upper and lower developmental threshold was estimated by the same authors between 34.4 and $14{ }^{\circ} \mathrm{C}$, with optimum development temperature at $30^{\circ} \mathrm{C}$. Larvae moth viability can be a cause of this low number, which was estimated by Torres et al. (2001) at $36.6 \%$. However, in the present study a sudden drop in larvae numbers in all cultivars was reported, which was mainly due to insecticide use.

The introduction of T. absoluta in Algeria was not followed by its parasitic procession. Hence, the search for their natural antagonists during this study has resulted in no capture, likely due to chemical use against pests. Miranda et al. (1998) estimated that T. absoluta antagonists may be responsible for $79.4 \%$ of larval mortality.

Eggs can be found on all tomato parts, but T. absoluta prefers to lay their eggs on leaves (Torres et al. 2001). According to Bawin et al. (2014), oviposition site choice of females was dependent on infestation level. Quantitative egg evaluation should improve the control against this pest and at the same time reduce losses (Torres et al. 2001). The average number of eggs laid on leaves on all cultivars remains low due to temperature or egg mortality; it can also be due to chemical pest management. The 'Toufan' cultivar was less attractive with respect to female egg deposits. Egg infertility can be a cause (Miranda et al. 2005). Fecundity of T. absoluta varied depending on temperature (Mahdi et al. 2011) as well as on reproduction efficiency (Berkani, Badaoui 2008). Cherif et al. (2013) indicated that cultivars 'Chebli' and 'Shams' were less suitable for T. absoluta egglaying. Freitas et al. (1998) highlighted that compounds such as sesquiterpenes found in leaves trichomes have an inhibitory effect on T. absoluta female activity.

Arno and Gabarra (2011) noted that tomato plants can be infested from seedlings to mature plant. All cultivars in this study were attacked by T. absoluta; they hosted all larval stages. An important pest presence caused damage to most tomato cultivars. They can cause serious damage to plants including complete crop destruction (Gil 2015). The work of Oliveira et al. (2009) showed that no known tomato cultivar was resistant to this pest. This could be associated, according to the same authors, to reduced genetic variability of tomato. The severity of T. absoluta attacks on tomato cultivars was confirmed by the work of Leite et al. (2001). They showed that certain cultivars that have little or no allelochemicals during the various vegetative phases with low infection rates, causing increased tomato sensitivity to larval attacks. Gilardon et al. (2001) reported that some wild tomato species such as Lycopersicon hirsutum were known to be resistant to T. absoluta. Farrar and Kennedy (1991) explained that identified compounds in glandular leaves trichomes of some wild tomato cultivars constitute physical and chemical barriers to insects and pathogens. Sohrabi et al. (2016) found that high density of leaf trichomes can help resistance to T. absoluta attacks in 'Berlina,' 'Zaman', and 'Golsar' cultivars.

Tomato fruits were free of leaf miner larvae at the beginning of the observation period (autumn and winter) on all cultivars. During the spring period the percentage of damage increased, presumably due to larval development related to rise in temperature. Martins et al. (2016) reported an increase in damage when temperature was close to 30 ${ }^{\circ} \mathrm{C}$. T. absoluta can visit several tomato fruits causing substantial damage to greenhouse crops, sometimes destroying the entire production (Berkani, Badaoui 2008; Lacordaire, Feuvrier 2010). The same was observed by Harbi et al. (2015) where a maximum of $2 \%$ of infested fruits was observed at the beginning of the growing season and later reached $11 \%$. Chermiti et al. (2009) estimated tomato fruit losses between 11.08 and $43.33 \%$; Karut et al. (2011) at 38.4\% and Harbi et al. (2012) at 31.4\%. Cocco et al. (2015) evaluated tomato fruits damaged by larvae at $27 \%$. These same authors emphasised that this is a consequence of increased density of $T$. absoluta on leaves. The severity of attack on the three cultivars was different in the present study with the 'Sahara' cultivar having the most damage. Larger populations of leaf miner due to higher temperatures induced fruit losses (Chermiti et al. 2009). The same authors affirmed that symptoms and damage caused by T. absoluta were correlated with population density. The same was observed in this study, with population changes of fourth larvae on all tomato cultivars at the end of tomato phenological cycle.

Overall, T. absoluta behaviour towards all tomato cultivars was different. However, 'Dawson' and 'Toufan' cultivars seems most prefered for cultivation in the region of Biskra, as they hosted fewer larvae than the 'Sahara' cultivar. Integrated pest management that is less aggressive towards antagonists and the environment could be an option to reduce crop losses. Junior et al. (2007) believed that insect resistant cultivars could even reduce insecticide applications on crops. Insect-proof crops combined with sex pheromone mass trapping (Harbi et al. 2015) and resistant cultivars can be efficient means to control T. absoluta. Thus, this study has drawn attention to the absence of antagonists in tomato greenhouses. Preventive chemical applications on tomato crops seem to be the main culprit.

\section{Acknowledgements}

The study was supported by the CNEPRU project $\left(\mathrm{F}^{\star} 01420130071\right)$. The authors thank M. Khadraoui Y. for his collaboration during the study. We thank also Dr. L. Ernoul for correcting the English. 


\section{References}

Allache F., Bouta Y., Demnati F. 2015. Population development of the tomato moth Tuta absoluta (Lepidoptera: Gelechiidae) in greenhouse tomato in Biskra, Algeria. J. Crop Prot. 4: 509-517.

Allache F., Demnati F. 2012. Population changes of Tuta absoluta (Mey.) (Lepidoptera, Gelichiidae): a new introduced tomato crop pest at Biskra in Algeria. Jordan J. Agri. Sci. 8: 391-400.

Allache F., Houhou M.A., Osmane I., Naili L., Demnati F. 2012. Suivi de l'évolution de la population de Tuta absoluta Meyrick (Gelichiidae), un nouveau ravageur de la tomate sous serre à Biskra (sud-est d'Algérie). Entomol. Faun. Faun. Entomol. 65: 149-155.

Arno J., Gabarra R. 2011. Side effects of selected insecticides on Tuta absoluta (Lepidoptera: Gelechiidae) predators Macrolophus pygmaeus and Nesidiocoris tenuis (Hemiptera: Miridae). J. Pest Sci. 84: 513-520.

Barrientos Z.R., Apablaza H.J., Norero S.A., Estay P.P. 1998. Threshold temperature and thermal constant for development of the South American tomato moth, Tuta absoluta (Lepidoptera, Gelechiidae). Ciênc. Investig. Agrar. 25: 133-137.

Bawin T., De Backer L., Dujeu D., Legrand P., Caparros-Megido R., Francis F., Verheggen F.J. 2014. Infestation level influences oviposition site selection in the tomato leafminer Tuta absoluta (Lepidoptera: Gelechiidae). Insects 5: 877-884.

Berkani A., Badaoui M.I. 2008. La mineuse de la tomate Tuta absoluta Meyrick 1917 (Lepidoptera: Gelechiidae). Annales de l'Institut National de la Recherche Agronomique d'Algérie 4: $1-16$.

Caparros-Megido R., Haubruge E., Verheggen F.J. 2012. First evidence of deuterotokous parthenogenesis in the tomato leafminer, Tuta absoluta (Meyrick) (Lep., Gelechiidae). J. Pest Sci. 85: 409-412.

Caparros-Megido R., Haubruge E., Verheggen F.J. 2013. Pheromone-based management strategies to control the tomato leafminer, Tuta absoluta (Lepidoptera: Gelechiidae). Biotech. Agron. Soc. Environ. 17: 475-482.

Chaux C.L., Foury C.L. 1994. Cultures légumières et maraichères. Légumineuses potagères, légumes et fruits. Lavoisier, Paris. $563 p$.

Cherif A., Mansour R., Grissa-Lebdi K. 2013. Biological aspects of tomato leafminer Tuta absoluta (Lepidoptera: Gelechiidae) in conditions of Northeastern Tunisia: possible implications for pest management. Environ. Exp. Biol. 11: 179-184.

Chermiti B., Abbes K., Aoun M., Ben Othmane S., Ouhibi M., Gamoon W., Kacem S. 2009. First estimates of the damage of Tuta absoluta (Povolny) (Lepidoptera: Gelechiidae) and evaluation of the efficiency of sex pheromone traps in greenhouses of tomato crops in Bekalta region, Tunisia. Afr. J. Plant Sci. Biotechnol. 3: 49-52.

Chougar S., Medjdoub-Bensaad F. 2014. Biologie et dynamique des populations de Tuta absoluta (Meyrick, 1917) sur deux variétés de tomate ('Dawson' et Zahra) sur le littoral de la région de Tizi-Ouzou. AFPP - Dixième Conférence Internationale sur les Ravageurs en Agriculture Montpellier - 22 et 23 Octobre 2014.

Cocco A., Deliperi S., Lentini A., Mannu R., Delrio G.2015.Seasonal phenology of Tuta absoluta (Lepidoptera: Gelechiidae) in protected and open-field crops under Mediterranean climatic conditions. Phytoparasitica 43:713-724.

Desneux N., Wajnberg E., Wyckhuys K.A.G., Burgio G., Arpaia S., Narvaez-Vasquez C.A., Gonzalez-Cabrera J., Ruescas D.C.,
Tabone E., Frandon J., Pizzol J., Poncet C., Cabello T., Urbaneja A. 2010. Biological invasion of European tomato crops by Tuta absoluta: ecology, geographic expansion and prospects for biological control. J. Pest Sci. 83: 197-215.

DSA Biskra. 2014. Direction des statistiques agricoles, Biskra, Algérie.

Elouissi M., Berkani A. 2015. Contribution to the study of some biological aspects of Tuta absoluta in the region of Mascara (Algeria). J. Chem. Pharm. Res. 7: 447-451.

Freitas A., Cardoso M.G., Maluf E.R., Santos C.D., Nelson D.L., Costa J.T., Souza E.C., Spada L. 1998. Identificaçao do sesquiterpino, zingibereno, aleloquimicho responsavel pelaresistencia à Tuta absoluta (Meyrick, 1917) nacultura do tomateiro. Ciên. Agrotec. 22: 483-487.

Farrar R.R., Kennedy G.G. 1991. Relationship of leaf lamellarbased resistance to Leptinotarsa decemlineata and Heliothis zea in a wild tomato, Lycopersicon hirsutum f. glabratum, PI 134417. Entomol. Exp. Appl. 58: 61-67.

Gebremariam G. 2015. Tuta absoluta: a global looming challenge in tomato production. J. Biol. Agric. Healthcare 5: 57-62.

Gilardon E., Pocovi M., Hernández C., Olsen A. 2001. Role of tomato leaf glandular trichomes on oviposition of Tuta absoluta. Pesq. Agrop. Bras. 36: 585-588.

Ghoneim K. 2014. Parasitic insects and mites as potential biocontrol agents for a devastative pest of tomato, Tuta absoluta Meyrick (Lepidoptera: Gelechiidae) in the world: a review. Int. J. Adv. Res. 2: 81-115.

Gil M.A.2015. Insect resistance in tomato (Solanum spp.). Cultivos Tropicales 36: 100-110.

Guenaoui Y. 2008. Nouveau ravageur de la tomate en Algérie: Première observation de Tuta absoluta, mineuse de la tomate invasive, dans la région de Mostaganem, au printemps 2008. Phytoma La Défense des Végétaux 617: 18-19.

Harbi A., Abbes K., Chermiti B. 2012. Evaluation of two methods for the protection of tomato crops against the tomato leafminer Tuta absoluta (Meyrick) under greenhouses in Tunisia. EPPO Bull. 42: 317-321.

Harbi A., Abbes K., Dridi-Almohandes B., Chermiti B. 2015. Efficacy of insect-proof nets used in Tunisian tomato greenhouses against Tuta absoluta (Meyrick) (Lepidoptera: Gelechiidae) and potential impact on plant growth and fruit quality. J. Entomol. Acarol. Res. 47: 109-116.

Junior A.L.B., Macedo M.A.A., Torres A.L., Angelini M.R. 2007. Late pest control in determinate tomato cultivars. Sci. Agric. 64: 589-594.

Kaoud H.A. 2014. Alternative methods for the control of Tuta absoluta. Glob. J. Mul. App. Sci. 2: 41-46.

Karut K., Kazak C., Doker I., Ulusoy M.R. 2011. Pest status and prevalence of tomato moth Tuta absoluta (Meyrick 1917) (Lepidoptera: Gelechiidae) in tomato growing greenhouses of Mersin. Turk. Bull. Entomol. 35: 339-347.

Lacordaire A.I., Feuvrier E. 2010. Tomate, traquer Tuta absoluta. Phytoma La Défense des Végétaux 632: 40-44.

Lange W.H., Bronson L. 1981. Insect pests of tomatoes. Annu. Rev. Entomol. 26: 345-371.

Lebdi-Grissa K., Skander M., Mhafdhi M., Bel-Hadj R. 2010. Lutte intégrée contre la mineuse de la tomate, Tuta absoluta Meyrick (Lepidoptera: Gelechiidae) en Tunisie. Entomol. Faun. Faun. Entomol. 63: 125-132.

Leite G.L., Picanço M., Guedes R.N., Zanuncio J.C. 2001. Role of plant age in the resistance of Lycopersicon hirsutum f. glabratum to the tomato leafminer Tuta absoluta 
(Lepidoptera:Gelechiidae). Sci. Hortic. 89: 103-113.

Lietti M.M.M., Botto E.,Alzogaray R.A. 2005. Insecticide resistance in Argentine populations of Tuta absoluta (Lepidoptera: Gelechiidae). Neotrop. Entomol. 34: 113-119.

Mahdi K., Doumandji-Mitiche B., Ababsia A., Doumandji S. 2011. Les ennemis naturels de la mineuse de la tomate Tuta absoluta (Meyrick, 1917) en Algérie: perspectives de lutte biologique. AFPP- Quatrième conférence internationale sur les méthodes alternatives en protection des cultures, Lille- 8, 9 et 10 Mars 2011.

Martins J.C., Picanço M.C., Bacci L., Guedes R.N.C., Santana Jr. P.A., Ferreira D.O., Chediak M. 2016. Life table determination of thermal requirements of the tomato borer Tuta absoluta. J. Pest Sci. 89: 897-908.

Miranda M.M.M., Picanço M.C., Zanuncio J.C., Guedes R.N.C. 1998. Ecological life table of Tuta absoluta (Meyrick) (Lepidoptera: Gelichiidae). Biocontrol Sci. Technol. 8: 597-606.

Miranda M.M.M., Picanço M.C., Zanuncio J.C., Bacci L., Silva D.E.M. 2005. Impact of integrated pest management on the population of leafminers, fruit borers, and natural enemies in tomato. Cienc. Rural 35: 204-208.

Oliveira F.A., da Silva D.J.H., Leite G.L.D., Jham G.N., Picanço M. 2009. Resistance of 57 greenhouse-grown accessions of Lycopersicon esculentum and three cultivars to Tuta absoluta (Meyrick) (Lepidoptera: Gelechiidae). Sci. Hort. 119: 182-187.

Retta A.N., Berhe D.H. 2015. Tomato leaf miner - Tuta absoluta (Meyrick), a devastating pest of tomatoes in the highlands of
Northern Ethiopia: a call for attention and action. Res. J. Agric. Environ. Manage. 4: 264-269.

Silvério F.O., de Alvarenga E.S., Morenob S.C., Picanço M.C. 2009. Synthesis and insecticidal activity of new pyrethroids. Pest Manage. Sci. 65: 900-905.

Siqueira H.A.A., Guedes R.N.C., Picanço M.C. 2000. Insecticide resistance in populations of Tuta absoluta (Lepidoptera: Gelechiidae). Agr. Forest Entomol. 2: 147-153.

Sohrabi F., Nooryazdan H.R., Gharati B., Saeidi Z. 2017. Plant resistance to the moth Tuta absoluta (Meyrick) (Lepidoptera: Gelechiidae) in tomato cultivars. Neotrop. Entomol. 46: 293209.

Sridhar V., Nitin K.S., Onkara Naik S., Nagaraja T. 2015. Comparative biology of South American tomato moth, Tuta absoluta (Meyrick) (Lepidoptera: Gelechiidae) on three solanaceous host plants. Pest Manage. Horticult. Ecosyst. 21: 159-161.

Terzidis A.N., Wilcockson S., Leifert C. 2014. The tomato leaf miner (Tuta absoluta): conventional pest problem, organic management solutions?. Org. Agr. 4: 43-61.

Torres J.B., Faria C.A., Evangelista Jr.W.S., Pratissoli D. 2001. Within-plant distribution of the leaf miner Tuta absoluta (Meyrick) immatures in processing tomatoes, with notes on plant phenology. Int. J. Pest Manage. 47: 173-178.

Urbaneja A., Vercher R., Navarro V., Garcia Mari F., Porcuna J.L. 2007. The tomato leafminer, Tuta absoluta. Phytoma 194: 1623. 